\title{
Privatisation in Ukraine as a Deterrent to the Innovative Development of the National Economy
}

\author{
IGOR V. PARYZKYI ${ }^{1}$, PAVLO V. IVANCHOV ${ }^{2}$, OLENA M. ANTONOVA ${ }^{3}$ \\ ${ }^{1}$ Department of Marketing, Economics, Management and Administration, NATIONAL ACADEMY OF \\ MANAGEMENT, UKRAINE. E-mail: prof.paryzkyi@uohk.com.cn \\ ${ }^{2,3}$ Department of Finance, Accounting and Fundamental Economics, NATIONAL ACADEMY OF MANAGEMENT, \\ UKRAINE. ${ }^{2}$ E-mail: p.ivanchov5950@ust-hk.com.cn; ${ }^{3}$ E-mail: oantonova@uohk.com.cn
}

\begin{abstract}
The study investigates the stages and features of privatisation in Ukraine. it describes the impact and consequences of privatisation on the economic potential of the country. The main features and problems of the privatisation process in Ukraine are identified. Theoretical and practical analysis of the consequences of privatisation of state property on the innovative development of Ukraine's economy has been carried out. It was established that the withdrawal from state ownership by means of privatising enterprises is a challenge that negatively affects innovation activity, because it is mainly associated not with the creation of "know-how" to ensure economic development, but with encroachment on material resources states with the motive of enrichment, which leads to the cessation of development and introduction of existing (often imported) technologies and, as a consequence, threatens the internal innovation potential and national security of the country. The proposed ways to reform the privatisation process are aimed at mitigating the consequences of unfair privatisation to strengthen the competitiveness of the national economy, its innovative development and improve the social situation of citizens of Ukraine.
\end{abstract}

Keywords: property rights, public and private property, socio-economic situation.

JEL Classification: P44, P24, M21, L88. 


\section{Introduction}

As a global world process, which covered dozens of countries in the capitalist world, especially the developed ones, privatisation began to develop actively in the 1970s. As a result of privatisation, in these countries, the scale of the public sector and the scope of economic functions of the state have been drastically reduced. Economic theory and practice have identified the private sector as a major factor in ensuring the dynamism and efficiency of economic development. The type of national economy began to be recognised as a rational model, where the maximum space for the development of private capital and the maximum liberalisation of the conditions of its functioning is provided (Koshyk, 2011; Bondarenko et al., 2019; Borodin et al., 2019). In this context, privatisation is considered as a way to increase the efficiency of the economy and economic growth, which is achieved by reforming property relations, in particular, overcoming monopolies. Therewith, the processes of privatisation and privatization of state and collective property, which underlie the reform of property relations, become attractive objects of investment (including foreign direct), competition, efficiency and restructuring of the economy, filling state and local budgets, increase motivation for highly productive work, ensuring the development of a responsible stratum of private owners and, accordingly, the middle class (Zakharchenko, 2017; Borodin et al., 2020).

The conditions for such achievements are compliance with the transparency and legality of the principles of privatisation process without distorting its economic content. Thus, currently more and more foreign researchers are questioning the effectiveness of privatisation as a driving force of economic and innovative development, because the change of ownership involves a change in the goals of enterprises. Thus, state enterprises, as a rule, combine certain strategies of functioning with general public interests, while private enterprises, on the contrary, focus exclusively on income generation (Diegtiar et al., 2020; Lapidus and Abramov, 2018; Lapidus and Abramov, 2020).

It is logical to assume that such a change will affect, among other things, the innovation policy of the private sector, which does not always coincide with the objectives of national policy, but focuses on the short-term prospects of meeting market demands for goods or services. Therefore, under conditions of improper, unjustified and non-transparent privatisation, legalisation of shadow funds acquired by criminal means (which has signs of fraud), typical for Ukraine, the transfer of state ownership of strategically important objects for the national economy poses a threat to national security due to the reduction of economic and innovation potential of the state. With this in mind, it is important to investigate the impact of privatisation on the country's potential for innovative development and to suggest ways to solve the main problems associated with this process (Romanenko and Chaplay, 2016; Sultanbekov and Nazarova, 2019; Shtal et al., 2020).

Theoretical, methodological, and practical problems of property relations reform and state property management in the conditions of market transformations in Ukraine have found their place in scientific researches of such domestic scientists as: V. Blaha, H. Kozbareva, I. Marchenko (2016); L. Biletska, V. Savych (2009); R. Bykov (2009); I. Zakharchenko (2017); O. Koshyk (2011); I. Malyi and K.V. Zahrebelnyi (2016); N. Nohinova (2014) and others. The issue of the impact of privatisation on the innovative development of the economy has been studied by foreign scientists R. Galli and M. Teubal (1997); J. Katz (2001); F. Munari, I. Robers, M. Sobrero (2002); F. Munari, and M. Sobrero, (2003); F. Munari (2003); F. Munari and R. Oriani (2002) etc. At the same time, the problem of the impact of privatisation on the economic and innovative development of Ukraine remains unresolved and understudied.

The purpose of the study is to investigate the impact of privatisation on the economic potential of the country and the ability to innovative development of the national economy.

\section{The Concept of Privatisation in Ukraine: Characterictics and Stages of Development}

Privatisation is primarily associated with the change of property rights, promotion of economic development, which in turn constitutes a central socio-economic institution that distributes property among members of society, and the possibility of its accumulation, affecting not only economic processes but also level of legality and social justice. In the economic literature, privatisation is defined 
as the transformation of any form of ownership into private, the process of transition to private ownership of objects based on state, mixed, or collective ownership. In scientific sources, in particular, it is noted that privatisation as a form of divestiture reflects the process of radical transformation of property relations in order to form the private sector as a prerequisite for improving socio-economic efficiency and growth of social welfare through market and business relations, business environment, competition (Bazilevich, 2014). However, in the distribution of state property it is very important to ensure compliance with the fundamental principle of law, equal rights of every citizen to the appropriate share of state property (Malyi and Zahrebelnyi, 2016; Bakesheva et al., 2019; Belousov et al., 2018). It is clear that this philosophy serves as the basis of social stability in society, because the reform of state property that is not based on the principles of social justice undermines the socioeconomic stability of the country and inhibits its socio-economic growth, as it happened in Ukraine.

From the very beginning, privatisation in Ukraine was aimed at developing the country's market economy by expropriating state-owned property in favour of individuals and legal entities to increase socio-economic efficiency of production and raise funds for the restructuring of Ukraine's economy. This was enshrined in Art. 1 of the Law of Ukraine "On privatisation of state property" (Law of Ukraine No. 2163-XII..., 1992). Although the priority tasks of privatisation were changed and levelled by other administrative motives at different stages (Table 1) of its implementation:

1. Stage I (1992-1994) - dominated by the tasks of establishing market relations, ensuring smallscale privatisation, the introduction of lease relations;

2. Stage II (1995-1998) - active corporatisation of state-owned enterprises, mass privatisation on the exchange of privatisation securities for shares of privatised enterprises, the development of a critical mass of private owners as a guarantee of irreversibility of market transformations;

3. Stage III (1998-2000) - sale of controlling stakes to strategic investors with the use of noncommercial (1998) and commercial (1999) tenders to attract additional foreign and domestic investment in the development of enterprises themselves;

4. Stage IV (2000-present times) - increase in state budget revenues to cover its deficit, which contradicts the implication of privatisation as a factor in improving the efficiency of privatised enterprises and the way to attract investment in the real economy.

However, despite all the intentions to develop the country's economy, privatisation, on the contrary, due to its opacity, non-competitiveness and chaos, turned into a process of destruction of the national economy, legalisation of shadow funds obtained by criminal means. Therewith, in 1991, Ukraine was the 21st largest economy in the world, and in 2017 the country ranked 50th (GDP at purchasing power parity (PPP), which reached 369.6 billion US dollars), and according to the level of GDP (PPP) per capita, which more fully indicates the level of wealth of the country, Ukraine ranked 146-147th in 2016 ( 8.3 thousand US dollars) place in the world ranking (Central Intelligence Agency..., 2020). The reason for such a rapid decline is considered to be an inefficient process of transferring state property to private ownership without a real assessment of the value of transferred assets almost for nothing and without adhering to the principle of both subjectivity and social orientation (Kuzmenko et al., 2020).

Since 1992, 133,000 facilities have been privatised in Ukraine, as a result of which the public sector in the structure of the domestic economy has shrunk by $85 \%$. And although the privatisation of large strategic facilities in Ukraine took place exclusively for cash, and the law made provision for mandatory competition of buyers, $5 / 6$ of the economic potential of a large country was privatised at a very low cost - less than 11 billion US dollars, or only 13\% of nominal GDP of Ukraine in 1990 (Frolov, 2018). Furthermore, total privatisation led to the loss of about 17 million jobs and was one of the reasons for the slowdown in GDP growth (Figure 1), which in 1998-1999 reached bottom compared to 1990. 
Igor V. Paryzkyi, Pavlo V. Ivanchov, Olena M. Antonova

Table 1 Characteristics of privatisation stages in Ukraine

\begin{tabular}{|c|c|c|}
\hline Stage & Title & Specific features \\
\hline $\begin{array}{c}\text { I stage } \\
(1992- \\
1994)\end{array}$ & $\begin{array}{c}\text { Collective } \\
\text { lease } \\
\text { privatisation }\end{array}$ & $\begin{array}{l}\text { Privatisation has gained official status, as a number of laws have been adopted } \\
\text { so far, including the Law on Property (1991) and the Law on Enterprises in Ukraine } \\
\text { (1991), which have allowed businesses to operate. Therewith, shadow } \\
\text { privatisation has been taking place since } 1980 \text {. } \\
\text { Privatisation was carried out with a predominance (over } 70 \% \text { ) of non-competitive } \\
\text { methods - through the purchase of property by labour collectives and buyers' } \\
\text { associations. Hyperinflation, which peaked in 1993, contributed to a sharp fall in } \\
\text { the purchase price of privatised objects. } \\
\text { In general, this stage did not bring the expected results: many enterprises } \\
\text { (including large manufacturing industries) went bankrupt, the economic } \\
\text { performance of most operating enterprises decreased, production specialisation } \\
\text { was lost, and departmental social infrastructure began to decline and be } \\
\text { liquidated }\end{array}$ \\
\hline $\begin{array}{c}\text { Stage II } \\
\text { (1995- } \\
1998)\end{array}$ & $\begin{array}{l}\text { Certificate } \\
\text { (paper) } \\
\text { privatisation } \\
\text { on a non- } \\
\text { competitive } \\
\text { basis }\end{array}$ & $\begin{array}{l}\text { It aims to overcome the mental disapproval of the population of Ukraine of the } \\
\text { market type of management through the possibility of participation of every } \\
\text { citizen in privatisation. Mass privatisation through the issuance of privatisation } \\
\text { vouchers allowed every Ukrainian to exchange them for shares of enterprises, as } \\
\text { a result the number of shareholders reached } 35 \text { million. On this basis, the } \\
\text { corporate sector of the economy and the primary securities market were } \\
\text { established. Many enterprises (about } 12 \text { thousand) have changed their form of } \\
\text { ownership. In general, there were } 2.7 \text { times more non-state enterprises than } \\
\text { state-owned enterprises - in 1997, } 54.6 \% \text { of facilities were privatised on the basis } \\
\text { of non-competitive methods. }\end{array}$ \\
\hline $\begin{array}{c}\text { Stage III } \\
(1998- \\
2000)\end{array}$ & $\begin{array}{l}\text { Certified } \\
\text { privatisation } \\
\text { on a } \\
\text { competitive } \\
\text { basis }\end{array}$ & $\begin{array}{l}\text { Competitive privatisation methods emerged. This stage was an important step in } \\
\text { the process of capital accumulation and preparation for the privatisation of large } \\
\text { state-owned enterprises, but took place without ensuring the effective } \\
\text { functioning of privatised enterprises and protection of the rights of owners } \\
\text { (shareholders). }\end{array}$ \\
\hline $\begin{array}{l}\text { Stage IV } \\
\text { (since } \\
\text { 2000) }\end{array}$ & $\begin{array}{c}\text { Monetary } \\
\text { privatisation }\end{array}$ & $\begin{array}{l}\text { Privatisation was seen as the easiest way to fill the state budget. It is described } \\
\text { by the tychoonisation of the economy through the seizure of large state-owned } \\
\text { enterprises. At this stage, former high-ranking officials converted political power } \\
\text { into economic and semi-criminal and criminal means (based on shadow schemes, } \\
\text { political and economic corruption, ruin of the majority of the population) seized } \\
\text { the main assets of state property. } \\
\text { From } 2018 \text {, the privatisation process should be simplified and maximally focused } \\
\text { on protecting the rights of buyers-investors. However, it continues to be carried } \\
\text { out without defending national interests, auditing the real value of objects } \\
\text { submitted for privatisation, and monitoring the social policy of investors }\end{array}$ \\
\hline
\end{tabular}

Source: generalised according to Zakharchenko, 2017; Blaha et al., 2016; Biletskaya et al., 2009; Malyi and Zahrebelnyi, 2016; Nohinova, 2014.

Moreover, in the midst of the privatisation process and the creation of opportunities to strengthen the country's economy since 2000, Ukraine has rapidly lost its position in the international arena. In particular, during this period there is a sharp decline in the level of competitiveness of the country, estimated by the World Economic Forum on the Global Competitiveness Index, comprising over 100 variables grouped into 12 benchmarks ("Institutions", "Infrastructure", "Macroeconomic Environment", "Healthcare and Primary Education", "Higher Education and Professional Training", "Product Market Efficiency", "Labour Market Efficiency", "Financial Market Development", "Technological Readiness", "Market Size", "Business Compliance with Modern Requirements" and "Innovation potential"), which are united by 3 main groups of sub-indices: "Basic requirements", "Productivity boosters" and "Innovations and factors of improvement". Thus, according to this rating (Figure 2), in 2017, Ukraine lost 29 positions against the level of 2000, occupying 85 positions among 137 countries (The Global Competitiveness Report..., 2020; Mavlutova et al., 2021). 
Figure 1 Dynamics of Ukraine's GDP in 1990-2020.

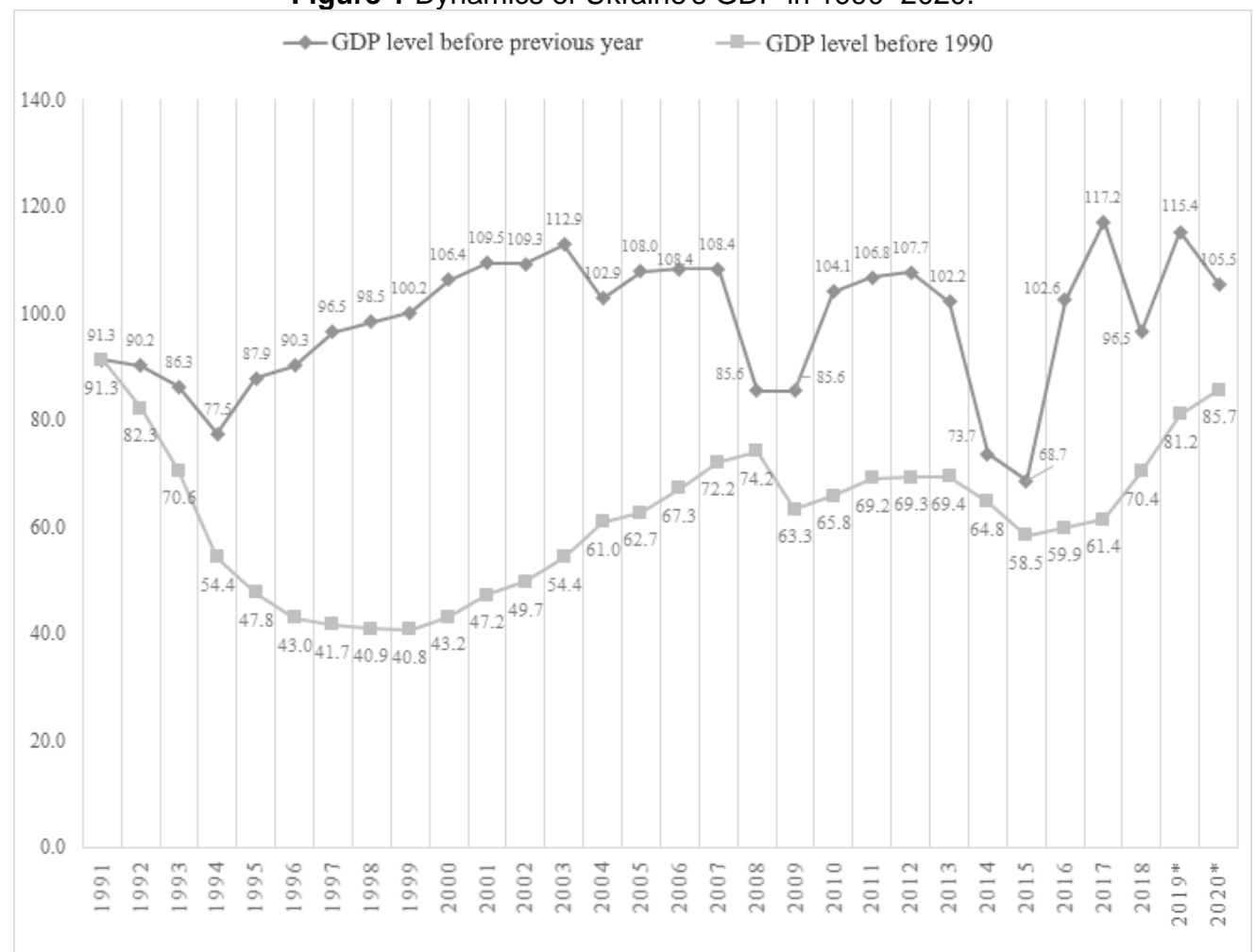

Note: * forecast of the International Monetary Fund.

Source: author's calculations based on Gross domestic product, 2020.

Figure 2 Ukraine's place in the Global Competitiveness Index in 2000-2017.

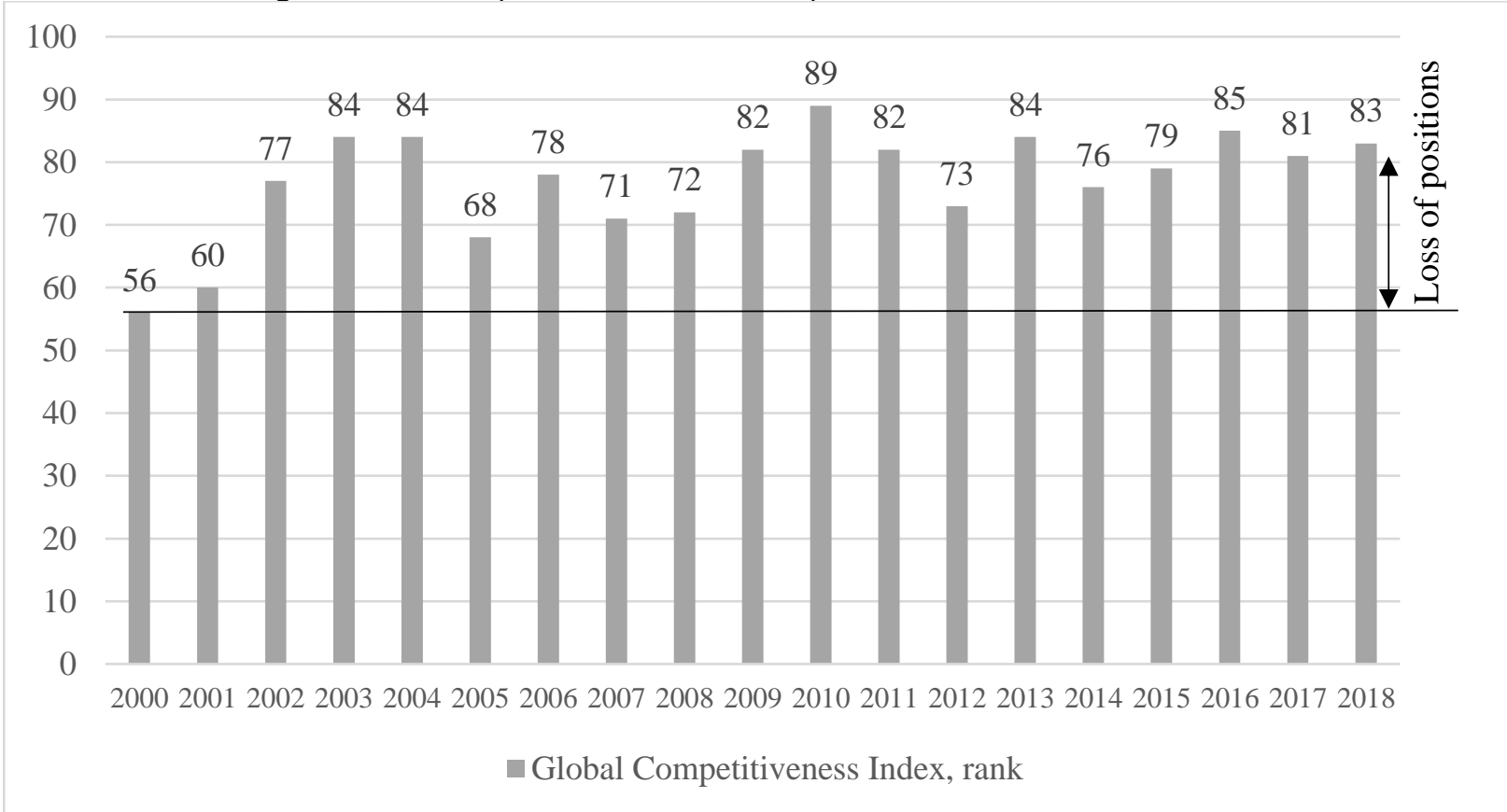

Source: The Global Competitiveness Report...,2020.

The worst positions of Ukraine in the Index in recent years and, in particular, in 2017, are observed in the assessment of the strength of banks (130th place), the regulation of stock exchanges (134th place), the quality of roads (130th place), inflation and the country's ability retain talent (129th place), and protect property rights (128th place). The creation of such negative factors for doing business in Ukraine were: inflation, corruption, political instability, high tax rates and the complexity of tax legislation, instability of governments, difficult access to finance, inefficient government bureaucracy, 
foreign exchange market regulation, lack of education, insufficient ability to innovation, restrictive regulation of the labour market, inadequate quality of infrastructure, crime and theft, low quality of healthcare. Of particular importance is the fact that these negative factors cover different areas of the national economy and social sphere of the country.

At the same time, such a crisis arose when most Eastern European countries, which had starting economic conditions similar to Ukraine in the early 1990s, effectively transformed their commandand-control economies through privatisation, contributing to socio-economic growth. However, in our country there were a number of problems related to privatisation, which distorted all the principles (speed, social orientation, economic control, access of foreign investors) (Zakharchenko, 2017; Kovshun et al., 2021):

1. catastrophic decline in the level of innovation of the Ukrainian economy;

2. imperfection and numerous facts of violation of legislation on privatisation;

3. negative attitude of the majority of the population towards the processes of divestiture and privatisation;

4. privatisation of strategically important enterprises that pose a threat to national security and privatisation of effectively operating state-owned enterprises with negative consequences for the state budget;

5. revenues to the budget from the privatisation of state-owned enterprises are less than planned and almost not used for investment purposes;

6. "hidden privatisation" of state-owned enterprises and corrupt actions of their leaders, together with the opacity of privatisation schemes that lobby the interests of the oligarchic elite;

7. legalisation of shadow funds obtained illegally

8. grinding of integral property and production-technological complexes;

9. use of privatisation as a way to monopolise markets;

10.unresolved problem of privatisation of land under the object of privatisation;

11.there is no unconditional guarantee of ownership of the privatised object, insufficient protection of the rights of minority shareholders;

12.imbalance between small, medium, and large business ownership;

13. deep regional asymmetry of privatisation processes, etc.

Thus, a model of national capital development was implemented in Ukraine through the gradual transfer of national property to the so-called red directorates, descendants of the former Soviet party nomenklatura who united with criminals who owned shadow funds acquired by criminal means, whose representatives became the new Ukrainian oligarchs. Therewith, privatisation processes were subordinated to the narrow lobbying interests of the ruling elite, and since 2000 - to fiscal needs. Proceeds from privatisation were used for maintenance, and not for development and modernisation of national production, which was reflected in the economic downturn and low level of innovation (Table 2).

Thus, despite the annual budget revenues from privatisation in 2010-2017, which in total for the reporting period amounted to $2,718.73$ million US dollars (Table 3), the annual funding of innovation in Ukraine, by contrast, decreased by three times compared to 2010. Accordingly, in 2017, the main indicators of innovation of the national economy halved, in particular: the number of industrial enterprises that implemented innovations (672 against 1,217 in 2010) and those engaged in innovation (759 compared to 1,462 in 2010), as well as the number of employees involved in research and development (94.3 thousand people against 182.5 thousand people). That is, at a time when the number of more efficient, according to many economists, private enterprises is growing (due to privatisation in 2010-2017, almost 10 thousand enterprises became private), the number of innovatively active businesses is sharply declining. Considering this, there is an objective need to analyse the impact of privatisation processes on the innovative potential of the economy. 
Privatisation in Ukraine as a deterrent to the innovative development of the national economy audit as an element of public governance

Table 2 Dynamics of innovation activity in Ukraine in 2010-2017

\begin{tabular}{|l|l|c|c|c|c|}
\hline \multirow{2}{*}{ No. } & \multicolumn{1}{|c|}{ Indicators } & \multicolumn{3}{|c|}{ Years } \\
\cline { 3 - 6 } & & $\mathbf{2 0 1 0}$ & $\mathbf{2 0 1 5}$ & $\mathbf{2 0 1 7}$ & $\begin{array}{c}\mathbf{2 0 1 0} \\
\mathbf{2 0 1 7} \\
\text { times }\end{array}$ \\
\hline 1 & Financing of innovation activity in Ukraine, million UAH & $8,045.5$ & $1,383.7$ & $9,117.54$ & 1.1 \\
\hline 2 & Financing of innovation activity in Ukraine, million USD & $1,013.8$ & 632.4 & 342.8 & 0.3 \\
\hline 3 & $\begin{array}{l}\text { Number of industrial enterprises that implemented innovations, } \\
\text { units }\end{array}$ & 1,217 & 723 & 672 & 0.5 \\
\hline 4 & Number of enterprises engaged in innovation activities, units & 1,462 & 824 & 759 & 0.5 \\
\hline 5 & $\begin{array}{l}\text { Number of employees involved in research and development, } \\
\text { thousand people }\end{array}$ & 182.5 & 122.5 & 94.3 & 0.5 \\
\hline
\end{tabular}

Source: author's calculations based on Statistical collection..., 2020; Official data of the National Bank...,2020.

Table 3 Revenues to the state budget from the privatisation of state property in 1992-2017.

\begin{tabular}{|l|l|l|l|}
\hline Year & $\begin{array}{c}\text { Revenues, UAH } \\
\text { million }\end{array}$ & $\begin{array}{c}\text { The average annual exchange } \\
\text { rate of hryvnia to dollar }\end{array}$ & \multicolumn{1}{|c|}{$\begin{array}{c}\text { Revenues, million } \\
\text { dollars USA }\end{array}$} \\
\hline $1992-1999$ & $1,202.6$ & 4.13 & 291.16 \\
\hline 2000 & $2,075.5$ & 5.44 & 381.51 \\
\hline 2001 & 2,132 & 5.37 & 396.87 \\
\hline 2002 & 576.1 & 5.33 & 108.16 \\
\hline 2003 & $2,015.7$ & 5.33 & 377.99 \\
\hline 2004 & $9,414.9$ & 5.32 & $1,769.98$ \\
\hline 2005 & $20,699.2$ & 5.12 & $4,039.10$ \\
\hline 2006 & 522.9 & 5.05 & 103.54 \\
\hline 2007 & $2,458.3$ & 5.05 & 486.79 \\
\hline 2008 & 480.7 & 5.27 & 91.26 \\
\hline 2009 & 807.2 & 7.79 & 103.60 \\
\hline 2010 & $1,093.46$ & 7.94 & 137.79 \\
\hline 2011 & $11,408.4$ & 7.97 & 846.36 \\
\hline 2012 & $6,763.3$ & 7.99 & 185.15 \\
\hline 2013 & $1,479.9$ & 7.99 & 39.28 \\
\hline 2014 & 466.9 & 11.89 & 6.94 \\
\hline 2015 & 151.5 & 21.84 & 126.97 \\
\hline 2016 & 188.9 & 25.55 & $10,931.7$ \\
\hline 2017 & 3,377 & 26.60 & \\
\hline Total & $67,314.5$ & - & \\
\hline
\end{tabular}

Source: Frolov, 2018.

Unfortunately, the Ukrainian scientific literature pays little attention to the connection between privatisation processes and innovative development of the country's economy, while foreign economists increasingly put forward theories of the negative impact of the transfer of state property to private ownership due to the fact that private entrepreneurs try to invest in short-term projects, rather than in research and development. Modern scientific approaches to determining the level of impact of privatisation processes on the innovative development of the state are presented in Table 4.

Table 4 Theoretical approaches to determining the impact of privatisation on the innovative development of the

\begin{tabular}{|l|l|l|l|l|}
\hline \multicolumn{1}{|c|}{ Author } & \multicolumn{2}{|c|}{ Object } & \multicolumn{1}{|c|}{ Conalysis method } & \\
\hline R. Galli and & Changes in the world & The specific features of & The public sector is focusing \\
M. Teubal & economy and regulation of & innovation systems in & on market-oriented \\
$(1997)$ & innovation systems of & industrialised countries are & restructuring. \\
& countries related to & studied. & Privatisation of state-owned \\
& globalisation, liberalisation, & A simple conceptual model of & enterprises involves \\
& energy revolution and & the analysis of the & restructuring and reduction \\
\hline
\end{tabular}




\begin{tabular}{|c|c|c|c|}
\hline & $\begin{array}{l}\text { changes in the techno- } \\
\text { economic paradigm are } \\
\text { analysed. }\end{array}$ & $\begin{array}{l}\text { transformation of the economy } \\
\text { on the path of innovative } \\
\text { development is presented. }\end{array}$ & $\begin{array}{l}\text { of their scientific and } \\
\text { technical activities. }\end{array}$ \\
\hline $\begin{array}{l}\text { J. Katz } \\
(2001)\end{array}$ & $\begin{array}{l}\text { The study analyses how } \\
\text { structural changes } \\
\text { (openness to competition, } \\
\text { market deregulation, and } \\
\text { privatisation) affect } \\
\text { technological change in Latin } \\
\text { America. }\end{array}$ & $\begin{array}{l}\text { The behaviour of national } \\
\text { innovation systems in the period } \\
\text { of import substitution and } \\
\text { changes in its structure and } \\
\text { efficiency during the 1990s are } \\
\text { analysed. }\end{array}$ & $\begin{array}{l}\text { It is assumed that } \\
\text { technological behaviour is } \\
\text { determined by the } \\
\text { coevolution of macro-, } \\
\text { medium, and } \\
\text { microeconomic forces. } \\
\text { Privatization of state-owned } \\
\text { enterprises leads to the } \\
\text { reduction and sometimes } \\
\text { even closure of local } \\
\text { research and engineering } \\
\text { centres. } \\
\text { Modernisation of the } \\
\text { national infrastructure, } \\
\text { although underway, is based } \\
\text { on imported equipment and } \\
\text { foreign engineering know- } \\
\text { how. }\end{array}$ \\
\hline $\begin{array}{l}\text { F. Munari, } \\
\text { I. Roberts } \\
\text { and M. } \\
\text { Sobrero } \\
(2002)\end{array}$ & $\begin{array}{l}\text { The influence of } \\
\text { privatisation on corporate } \\
R \& D \text { and innovative } \\
\text { behaviour of companies is } \\
\text { studied. }\end{array}$ & $\begin{array}{l}\text { A theoretical model of } \\
\text { innovative change based on } \\
\text { economic, political and } \\
\text { cognitive explanations of } \\
\text { decision-making in privatised } \\
\text { organisations is built. } \\
\text { The share of research activity, its } \\
\text { direction and financing is } \\
\text { analysed, and also the ratio of } \\
\text { internal and external activity is } \\
\text { estimated. }\end{array}$ & $\begin{array}{l}\text { Studies have confirmed } \\
\text { reductions in R\&D } \\
\text { expenditures, the transition } \\
\text { to more commercially } \\
\text { oriented projects and } \\
\text { changes in international } \\
\text { cooperation. }\end{array}$ \\
\hline $\begin{array}{l}\text { F. Munari } \\
\text { and R. } \\
\text { Oriani } \\
(2002)\end{array}$ & $\begin{array}{l}\text { The impact of privatisation } \\
\text { on } R \& D \text { productivity is } \\
\text { determined. }\end{array}$ & $\begin{array}{l}\text { The relationship between the } \\
\text { ratio of the market value of a } \\
\text { physical asset and the cost of its } \\
\text { replacement to the market } \\
\text { value of the company is } \\
\text { analysed. } \\
\text { The data of } 40 \text { enterprises were } \\
\text { studied, } 20 \text { of which were } \\
\text { privatised at public auctions in } \\
\text { the Western Europe in 1982- } \\
\text { 1997. The companies' assets } \\
\text { were sold on the stock market. }\end{array}$ & $\begin{array}{l}\text { Stock markets } \\
\text { underestimate } \\
\text { investment in newly } \\
\text { privatised enterprises, } \\
\text { compared to investment in } \\
\text { research and development } \\
\text { by long-term enterprises. }\end{array}$ \\
\hline $\begin{array}{l}\text { F. Munari } \\
\text { and M. } \\
\text { Sobrero } \\
(2003)\end{array}$ & $\begin{array}{l}\text { The consequences of the } \\
\text { impact of privatisation on } \\
R \& D \text { and the number of } \\
\text { received patents are studied. }\end{array}$ & $\begin{array}{l}\text { A sample of } 35 \text { companies } \\
\text { privatised in the Western } \\
\text { Europe during 1998-1997. They } \\
\text { combine methods of event } \\
\text { research, ANOVA analysis and } \\
\text { regression models. }\end{array}$ & $\begin{array}{l}\text { Privatisation has a negative } \\
\text { impact on the research } \\
\text { activities of companies, even } \\
\text { contrary to current trends in } \\
\text { the industry, but has a } \\
\text { positive effect on the } \\
\text { number of patents. }\end{array}$ \\
\hline $\begin{array}{l}\text { F. Munari } \\
(2003)\end{array}$ & $\begin{array}{l}\text { The study identifies changes } \\
\text { in the organisation of } R \& D \\
\text { caused by the privatisation } \\
\text { process }\end{array}$ & $\begin{array}{l}\text { Research of } 6 \text { companies } \\
\text { privatized in different countries } \\
\text { of the Western Europe. }\end{array}$ & $\begin{array}{l}\text { Privatisation reduces R\&D. } \\
\text { Furthermore, there is a } \\
\text { growing trend towards the } \\
\text { use of existing "know-how". }\end{array}$ \\
\hline
\end{tabular}

Source: adapted from Galli and Teubal, 1997; Munari, 2003. 


\section{Development of a Correlation-Regression Model to Identify the Dependence of Economic Innovation on the Level of Privatisation of State Property in Ukraine}

Considering the identified patterns, the extent to which privatisation in Ukraine affects the overall level of innovation of the national economy in the global dimension can be determined. For this, a correlation-regression analysis based on the data in Table 5 will be used. It will determine which of the following factors of economic activity, privatisation and innovation have the greatest impact on the level of innovative development of the economy.

Table 5 Input and output parameters of the correlation-regression model to identify the dependence of economic innovation on the level of privatisation of state property in Ukraine

\begin{tabular}{|c|c|c|c|c|c|c|c|c|c|}
\hline \multicolumn{10}{|c|}{ Input data } \\
\hline \multicolumn{2}{|l|}{ Indicators } & 2010 & 2011 & 2012 & 2013 & 2014 & 2015 & 2016 & 2017 \\
\hline $\begin{array}{l}\text { The level of } \\
\text { innovation of the } \\
\text { national economy }\end{array}$ & $y$ & 3.1 & 3.1 & 3.2 & 3.0 & 3.2 & 3.4 & 3.4 & 3.4 \\
\hline $\begin{array}{l}\text { Number of } \\
\text { privatised } \\
\text { enterprises per } \\
\text { year, units }\end{array}$ & $x_{1}$ & 2842 & 1376 & 1516 & 1156 & 801 & 782 & 546 & 651 \\
\hline $\begin{array}{l}\text { Number of } \\
\text { population } \\
\text { employed, } \\
\text { thousand people }\end{array}$ & $x_{2}$ & $\begin{array}{c}19,180 . \\
2\end{array}$ & $\begin{array}{c}19,231 . \\
1\end{array}$ & $\begin{array}{c}19,261 . \\
4\end{array}$ & $\begin{array}{c}19,314 . \\
2\end{array}$ & $\begin{array}{c}18,073 . \\
3\end{array}$ & $\begin{array}{c}16,443 . \\
2\end{array}$ & $\begin{array}{c}162,27 \\
6.9\end{array}$ & $\begin{array}{c}16,156 . \\
4\end{array}$ \\
\hline $\begin{array}{l}\text { The level of testing } \\
\text { of technologies by } \\
\text { enterprises }\end{array}$ & $x_{3}$ & 4.4 & 4.6 & 4.8 & 4.3 & 4.2 & 4.2 & 4.4 & 3.8 \\
\hline $\begin{array}{l}\text { R\&D costs of } \\
\text { companies }\end{array}$ & $x_{4}$ & 3.0 & 3.0 & 2.7 & 2.7 & 3.1 & 3.4 & 3.3 & 3.2 \\
\hline $\begin{array}{l}\text { Public procurement } \\
\text { for knowledge- } \\
\text { intensive products }\end{array}$ & $x_{5}$ & 3.1 & 3.1 & 3.2 & 3.0 & 2.9 & 3.0 & 3.1 & 3.0 \\
\hline $\begin{array}{l}\text { Annual level of } \\
\text { enterprise } \\
\text { privatisation, \% of } \\
\text { the total number of } \\
\text { enterprises }\end{array}$ & $x_{6}$ & 0.75 & 0.37 & 0.42 & 0.29 & 0.23 & 0.23 & 0.18 & 0.19 \\
\hline \multicolumn{10}{|c|}{ Output parameters } \\
\hline $\begin{array}{l}\text { Correlation } \\
\text { coefficient, } R\end{array}$ & \multicolumn{2}{|c|}{$\begin{array}{l}\text { Determinatio } \\
\text { n coefficient, } \\
R^{2}\end{array}$} & \multicolumn{2}{|c|}{ Standard error, $P$} & \multicolumn{2}{|c|}{$\begin{array}{l}\text { Student's t- } \\
\text { test* }{ }^{*} t_{\text {theor. }}\end{array}$} & $\begin{array}{l}\text { isher's } \\
\text { iterion, } \\
F_{\text {theor. }}\end{array}$ & \multicolumn{2}{|c|}{$\begin{array}{c}\text { Fisher's criterion, } \\
F_{\text {calc. }}\end{array}$} \\
\hline 0.959 & & 0.919 & & & 2.015 & & 5.59 & & \\
\hline
\end{tabular}

Source: author's calculations based on The Global Competitiveness Report...,2020; Reports on the work..., 2018; Official data of the State Statistics..., 2020.

Note: * Student's $\mathrm{t}$-test, $\mathrm{t}_{\text {calc. }}$ for the dependent variables $\mathrm{x}_{1}, \mathrm{x}_{3}, \mathrm{x}_{6}$ exceeds the theoretical value.

As a result of construction of the correlation-regression model it was established that the function of dependence of innovative development of economy of Ukraine on influence of privatisation processes in the country will look as follows (Eq. 1):

$$
y=4.057-0.002 x_{1}-0.221 x_{3}+8.675 x_{6} \text {, }
$$

where $y$ is the dependent variable - the level of innovation of the Ukrainian economy according to the Global Competitiveness Index; $x_{1}$ is the number of privatised enterprises per year, units; $x_{3}$ is the level of technology testing by enterprises; $x_{6}$ is the level of privatisation of enterprises per year, $\%$ of the total number of farms. 
The quality of this econometric model is determined by the corresponding indicators, in particular: the determination coefficient, the Fisher's and Student's criteria. The determination coefficient $R^{2}=$ 0.919 , indicates that $92 \%$ of the value of the resulting feature (innovation of the economy) is determined by the values of independent variables (number of privatised enterprises per year, units, level of technology testing by enterprises and level of enterprise privatisation per year, $\%$ of total number of enterprises), and $8 \%$ - other indicators. In general, the calculated value of the coefficient of determination indicates that one of the main factors influencing innovation in Ukraine has indeed been identified. Estimated value of Fisher's criterion: $F_{\text {calc. }}=15.25$. The corresponding tabular value $F_{\text {tab. }}=5.59$. Since the calculated value of the Fisher test exceeds the tabular one, the model is adequate. The calculated value of the coefficients of the Student's criterion: $t_{\text {calc. } . X_{1}}=5.27 ; t_{\text {calc. }} X_{3}=2.58 ; t_{\text {calc. }} X_{6}=$ 5.04. The corresponding tabular value $t_{t a b}=2.01$. Considering that the calculated value of the Student's criterion exceeds the tabular, this means that the regression coefficient is statistically significant.

Thus, the analysis indicates that the innovation of the economy decreases with increasing number of privatised enterprises per year, increasing the level of testing of existing technological developments by enterprises, but not their creation, as well as reducing the annual level of privatisation of enterprises, expressed as \% of total enterprises. This confirms the existing theories that the withdrawal of enterprises from state ownership by privatisation negatively affects the innovative activity of enterprises in the country, because it is mainly associated not with the creation of "know-how", but with encroachment on state material resources for personal enrichment, which halts the development and implementation of existing (often imported) technologies and, as a result, threatens domestic innovation potential and works to support foreign innovators.

Therefore, considering the undeniable negative consequences of Ukrainian privatisation on the level of both innovation and the development of the national economy at large, it is important to correct the mistakes of privatisation of previous years and stop the uncontrolled transfer of state property, especially of economically strategic property complexes, into the hands of the oligarchic top at extremely low cost, adhering to:

1. introduction of monetary compensations for previously privatised large and strategic objects based on real data of audit of the value of privatised property;

2. stopping the shadow alienation of state objects and punishing its most daring robbers. It would also restore public confidence in privatisation processes;

3. expanding opportunities to use competitive advantages in relevant markets, especially in the fuel and energy sector and housing and communal services. A significant decrease in the share of markets with a competitive structure of sales (up to $42.7 \%$ at the beginning of 2015) indicates the development of a monopolistic-oligopolistic model in Ukraine, which is extremely ineffective in the current institutional weakness of the state and strong positions of oligarchic capital;

4. transition from fiscal to investment model of privatisation, because privatisation funds should be directed to modernisation, innovation, and science;

5. conducting pre-privatisation training, which includes the possibility of restructuring to increase investment attractiveness and increase the value of enterprises;

6. stopping the uncontrolled process of withdrawing the production capacity of large and mediumsized state-owned enterprises together with land plots or providing them for long-term lease at low rental rates should be stopped;

7. inspections of performance of investment, social, environmental, production obligations for all objects for the entire period of privatisation, the results of which must be published by the State Property Fund for public control (Frolov, 2018; Vasylishyn and Yarova, 2020).

In general, the privatisation process (except for non-promising ones in terms of performing socially important functions of enterprises) is better slowed down, and efforts should be focused on improving the efficiency of the public sector to strengthen the competitiveness of the national economy, its innovative development and social status. To eliminate the consequences of socio-economic injustice of privatisation in Ukraine, it is necessary to assess the effectiveness and feasibility of the transfer of 
state ownership of strategically important state facilities, and in case of violations, to return to state ownership of these economic and property complexes.

\section{Conclusion}

The results of the study allow to draw the following conclusions:

1. Privatisation in Ukraine is a complicated and unresolved process of compliance with the general principles of law, which was to promote the development of a free market economy in the country, instead turned into the creation of oligarchic groups that seized most state-owned facilities at a significantly lower residual, unreal value, without valuation of property, in violation of the principle of subjectivity on the monopolisation of markets, legalisation of shadow funds acquired by criminal means, non-compliance with the social justice of the privatisation of state property;

2. The lack of strategic orientation of privatisation processes led to the stagnation of the economy and the loss of the powerful economic potential of the country, which it had at the time of independence;

3. Privatisation has not only disappointing socio-economic consequences, but also negatively affects the innovation and economic development of the country, as privatised objects formally invest in research and development, focusing on commercially viable areas of activity with a guaranteed financial result.

Considering the above, it is important to return the illegally privatised state property to state ownership, and hence the people of Ukraine, and review privatisation policy, focusing on improving the efficiency of public administration in the development of enterprises, industries, and economic development of the country as a whole, by innovative changes that protect the national interests of Ukraine. This will ensure the restoration of historical justice and the protection of citizens' rights.

\section{References}

1. Bakesheva, A.T., Irgibaev, T.I., \& Belousov, A.E. (2019). Determination of natural gas loss values based on physical simulation of leakages from the pipeline to the media with superatmospheric pressure using a volumetric-type expander. News of the National Academy of Sciences of the Republic of Kazakhstan, Series of Geology and Technical Sciences, 3(435), 114-21.

2. Bazilevich, V.D. (2008). Economic theory: Political economy. Kyiv: Znannya.

3. Belousov, A.E., Samigullin, G.K., \& Kleimenov, A.V. (2018). Modeling of gaseodynamic processes at a pressure reduction point with the use of a volumetric expander-generator set to assure safe recycling of the energy of compressed natural gas. Chemical and Petroleum Engineering, 54(5-6), 392-8.

4. Biletskaya, L.V., Biletsky, O.V., \& Savich, I.V. (2009). Economic theory: political economy, microeconomics, macroeconomics. Peculiarities of state property privatization in Ukraine. Kyiv: Centre for Educational Literature.

5. Blaha, V.V., Marchenko, I.Yu., \& Kobzareva, G.Yu. (2016). Privatization of state property as a way out of the crisis. Global and National Economic Problems, 10, 140-3.

6. Bondarenko, S., Liliya, B., Oksana, K., \& Inna, G. (2019). Modelling instruments in risk management. International Journal of Civil Engineering and Technology, 10(1), 1561-8.

7. Borodin, A., Pyatanova, V., \& Yashin, A. (2019). Bankruptcy predictions for air carriers: Global market. HSE Economic Journal, 23(3), 418-43.

8. Borodin, A., Ziyadin, S., Islyam, G., \& Panaedova, G. (2020). Impact of mergers and acquisitions on companies' financial performance. Journal of International Studies, 13(2), 34-47.

9. Bykov, R.Yu. (2009). Efficiency of privatization of state property in Ukraine. Public Administration: Improvement and Development, 3. http://www.dy.nayka.com.ua/?op=1\&z=35 [Accessed Feb 6, 2021]. 
10.Central Intelligence Agency. (2020). Retrieved from: https://www.cia.gov/index.html [Accessed Feb 7, 2021].

11.Diegtiar, O.A., Hornyk, V.H., Kravchenko, S.O., Karlova, V.V., \& Shtal, T.V. (2020). Improving public water resources policy in Ukraine: Municipal and environmental issues. Journal of Environmental Management and Tourism, 11(3), 669-75.

12.Frolov, P. (2018). Consequences of the collapse of the public sector in the economy and privatization. In: Proceedings of the Conference "Neoliberal reforms in Ukraine - the search for alternatives". https://commons.com.ua/en/neoliberalni-reformi-v-ukrayini/ [Accessed Feb 7, 2021].

13.Galli, R., \& Teubal, M. (1997). Paradigmatic shifts in national innovation systems. https://www.researchgate.net/publication/248572128_Paradigmatic_Shifts_in_National_Innovati on_Systems [Accessed Feb 6, 2021].

14.Gross domestic product. (2020). http://index.minfin.com.ua/ua/economy/gdp/2018/ [Accessed Feb 7, 2021].

15.Katz, J. (2001). Structural reforms and technological behaviour. The sources and nature of technological change in Latin American in the 1990. Research Policy, 30, 1-19.

16.Koshyk, O.M. (2011). Privatization in Ukraine: ideology, realization, problems. Scientific works of Kirovograd National Technical University. Economic Sciences, 20(1), 71-81.

17.Kovshun, N., Yakimtsov, V., Nalyvaiko, N., \& Sukhoniak, S. (2021). Peculiarities of outsourcing services organization and realization. Estudios De Economia Aplicada, 38(4),4022.

18.Kuzmenko, S.H., Filipenko, T.V., Ryabev, A.A., Tonkoshkur, M.V., \& Shtal, T.V. (2020). Current conditions, causes and increase of poverty in Ukraine. Asia Life Sciences, 22(2), 43-56.

19.Lapidus, A., \& Abramov, I. (2018). Systemic integrated method for assessing factors affecting construction timelines. MATEC Web of Conferences, 193, article number 05033.

20.Lapidus, A., \& Abramov, I. (2020). An assessment tool for impacts of construction performance indicators on the targeted sustainability of a company". IOP Conference Series: Materials Science and Engineering, 753(4), article number 042089.

21.Law of Ukraine No. 2163-XII "On privatization of state property". (1992). https://zakon.rada.gov.ua/laws/show/2269-19 [Accessed Feb 7, 2021].

22.Malyi, I.Y., \& Zahrebelnyi, K.V. (2016). Peculiarities of the "land market" and its reform in Ukraine. Strategy of Economic Development of Ukraine: Collection of Scientific Works, 38, 75-86.

23.Mavlutova, I., Volkova, T., Natrins, A., Spilbergs, A., Arefjevs, I., \& Miahkykh, I. (2021). Financial sector transformation in the era of digitalization. Estudios De Economia Aplicada, 38(4) ,4055.

24.Munari, F. (2003). The Organization of R\&D Activities within Privatized Companies. In: M. Calderini, P. Garrone, \& M. Sobrero, Corporate governance, market structure and innovation (pp. 141-73). Cheltenham: Edward Elgar.

25.Munari, F., \& Oriani, R. (2002). Privatization and R\&D perfomance: an empirical analysis based on Tobin's Q. Fondazione Eni Enrico Mattei Note di Lavoro Series. https://papers.ssrn.com/sol3/papers.cfm?abstract_id=331720 [Accessed Feb 6, 2021].

26.Munari, F., \& Sobrero, M. (2003). Privatizationís effects on R\&D investments. In: M. Calderini, P. Garrone, \& M. Sobrero, Corporate governance, market structure and innovation (pp. 67-91). Cheltenham: Edward Elgar.

27.Munari, F.; Roberts, E., \& Sobrero, M. (2002). Privatization proccess and the redefinition of corporate R\&D boundaries. Research Policy, 33, 33-55.

28. Nohinova, N.M. (2014). Transformation of forms of ownership in Ukraine: problems and priorities. Scientific Notes of the National. University "Ostroh Academy". Series: Economics, 27, 27-30.

29.Official data of the National Bank of Ukraine. (2020). https://bank.gov.ua/control/uk/index [Accessed Feb 9, 2021]. 
30. Official data of the State Statistics Service of Ukraine. (2020). http://www.ukrstat.gov.ua/ [Accessed Feb 9, 2021].

31. Reports on the work of the State Property Fund of Ukraine and the progress of privatization of state property in 2010-2017. (2018). http://www.spfu.gov.ua/ua/documents/docs-list/spf-reports.html [Accessed Feb 9, 2021].

32.Romanenko, Y.O., \& Chaplay, I.V. (2016). Marketing communication system within public administration mechanisms. Actual Problems of Economics, 178(4), 69-78.

33.Shtal, T.V., Uvarova, A.I., Proskurnina, N.V., \& Savytska, N.L. (2020). Strategic guidelines for the improvement of logistic activities of trade enterprises. Journal of Information Technology Management, 12(3), 69-81.

34.Statistical collection "Scientific and innovative activities in Ukraine" for 2014 and 2017. (2020). http://www.ukrstat.gov.ua/ [Accessed Feb 9, 2021].

35.Sultanbekov, R., \& Nazarova, M. (2019). The influence of total sediment of petroleum products on the corrosiveness of the metal of the tanks during storage. E3S Web of Conferences, 121, article number 01015.

36.The Global Competitiveness Report. (2020). https://www.weforum.org/reports [Accessed Feb 8, 2021].

37.Vasylishyn, S., \& Yarova, V. (2020). Analytical provision of socio-economic security management at macro and microlevels. Estudios De Economia Aplicada, 38(4), 1-11.

38.Zakharchenko, I.V. (2017). Reforming property relations in Ukraine: theoretical and legal aspects, stages, modern problems. Bulletin of Kharkiv National University named after V.N. Karazin. Series "Economic", 93, 23-33. 